dr inj. Emil Cegielny

prof. dr hab. inz. Stanistaw Pytel

Politechnika Krakowska.

\title{
Badanie przyczyny uszkodzenia zmęczeniowego osi lokomotywy EP 09-021
}

\begin{abstract}
Artykut dotyczy badań materiału osi lokomotywy EP09-021 w aspekcie ustalenia przyczyny jej uszkodzenia zmęczeniowego. Stwierdzono, że materiat pod względem składu chemicznego, własności mechanicznych, makro i mikrostruktury spetnia wymagania przedmiotowej normy. Badania fraktograficzne przetomu zmęczeniowego wykazaly, że jest on następstwem napoiny wykonanej $w$ strefie promienia przejściowego pomiędzy czopem spoczynkowym osi a częściq środkowq osi.
\end{abstract}

\section{Wstęp}

Złożony proces kontroli elementów i całego zestawu kołowego w procesie produkcji ograniczył w sposób radykalny możliwość wprowadzenia do eksploatacji zestawów wadliwych. Stosuje się w tym celu różnorodne metody badań i pomiarów, które pozwalają na eliminowanie elementów niepełnowartościowych, wyprodukowanych z materiałów o niewłaściwej jakości lub niezgodnie $\mathrm{z}$ obowiązującymi parametrami $\mathrm{w}$ procesie wytwarzania. Praktyka wykazuje jednak, że pomimo tego mamy do czynienia z losowymi uszkodzeniami takich elementów i układów funkcjonalnych.

Celem opracowania było przeprowadzenie badań laboratoryjnych materiału osi nr 341 lokomotywy EP09-021, zgodnie z normą PN-93/K-9146, oraz ustalenie przyczyny jej uszkodzenia zmęczeniowego. Z uwagi na złożoność problemu badania przeprowadzonow dwóch etapach. W etapie pierwszym przeprowadzono badania składu chemicznego, badania własności mechanicznych oraz badania makrostruktury i mikrostruktury materiału osi. Celem tych badań było potwierdzenie zgodności własności zastosowanej stali gatunku P35G z obowiązującym dokumentem normatywnym. Etap drugi badań poświęcono badaniom fraktograficznym, których celem było ustalenie przyczyny i mechanizmu uszkodzenia osi.

\section{Identyfikacja i ocena zlomu zmęczeniowego osi}

Złomy zmęczeniowe są istotnym źródłem informacji o charakterze poznawczym i użytkowym. $Z$ wyglądu określonych stref i cech złomu widocznych nieuzbrojonym okiem można ocenić w przybliżony sposób rodzaj i rozkład naprężeń jaki istniał w eksploatowanym elemencie lub zespole, kierunek naprężeń, rodzaj i wielkość przeciążeń [2]. Można też wnioskować o przyczynach zmęczeniowego zniszczenia, które można rozpatrywać jako:

- eksploatacyjne: warunki pracy, wpływ otoczenia, działanie ośrodków aktywnych,

- technologiczne: materiał, obróbka cieplna, obróbka mechaniczna,
- konstrukcyjne: kształt i wymiary, wpływ połączenia $\mathrm{z}$ innymi elementami.

Obraz powierzchni złomu zmęczeniowego, dla analizowanego przypadku osi zestawu kołowego lokomotywy elektrycznej serii EP09-021 przedstawiono na rys. 1 i 2.

Złom powstał $\mathrm{w}$ strefie promienia przejściowego pomiędzy czopem spoczynkowym osi (podpiaściem) a częścią środkową. Jest to typowa lokalizacja dla tego typu elementów z połączeniem wciskowym. Złom ma charakter typowy dla zmiennego obciążenia giętnoobrotowego, z wyraźnie usytuowanym ogniskiem i strefą przyogniskowa. Brak jest natomiast widocznych innych cech powierzchni złomów zmęczeniowych, takich jak np. uskoki pierwotne i wtórne. Wynika to $z$ faktu, że elementy po uszkodzeniu przemieszczały się względem siebie, prowadząc do powstania plastycznego nanoszenia produktów zużycia na powierzchnię złomu. Z dużym prawdopodobieństwem złom można zakwalifikować do grupy złomów plastycznokruchych. Dla uzyskania wymaganej wytrzymałości w połączeniach wciskowych koła jezdnego z osią zestawu kołowego stosuje się wartości wcisków prowadzące do odkształceń o charakterze sprężystoplastycznym. Stan naprężenia w tej strefie osi był więc czynnikiem intensyfikującym powstanie złomu o charakterze plastyczno-kruchym. Ocena makroskopowa badanego złomu prowadzi do wniosku, że jest on następstwem karbu technologicznego w strefie szczególnie wytężonej elementu. Nie można natomiast podać wniosków dotyczących dalszych propagacji pęknięcia z uwagi na naruszenie struktury złomu $\mathrm{w}$ procesie eksploatacji.

\section{Badania materiałowe osi}

W ramach badań materiałowych, zgodnie z normą PN-93/K-91046, wykonano analizę kontrolną składu chemicznego oraz przeprowadzono badania własności mechanicznych w oparciu o próbę statyczną rozciagania i próbę udarności oraz badania makrostruktury i mikrostruktury materiału osi uznając, że otrzymane 
wyniki mogą być źródłem ważnych informacji wyjaśniających relacje przyczynowo- skutkowe uszkodzenia osi.

Analizę składu chemicznego materiału uszkodzonej osi wykonano na powierzchni próbki 1 (rys. 7). Miejsce wykonania analizy obrazuje rys. 3. W badaniu składu chemicznego wykorzystano metodę spektrometryczna. Otrzymane wyniki przedstawiono w tabeli 1. Ostatnie dwa wiersze w tabeli zawierają informację o maksymalnym udziale procentowym pierwiastków, wymienionych w normie PN-91/H-84027/03 i karcie UIC 811-1, dla materiału osi P35G (A1).

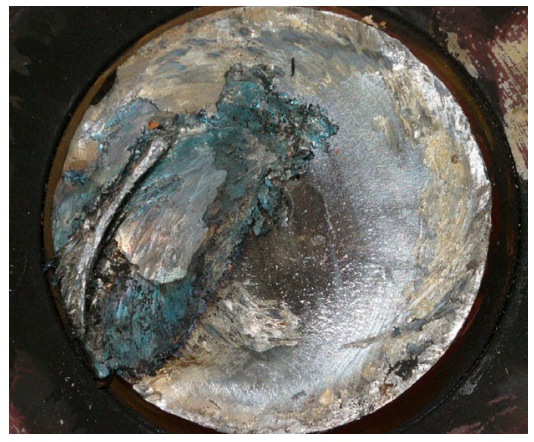

Rys. 1. Złom zmęczeniowy osi od strony koła jezdnego

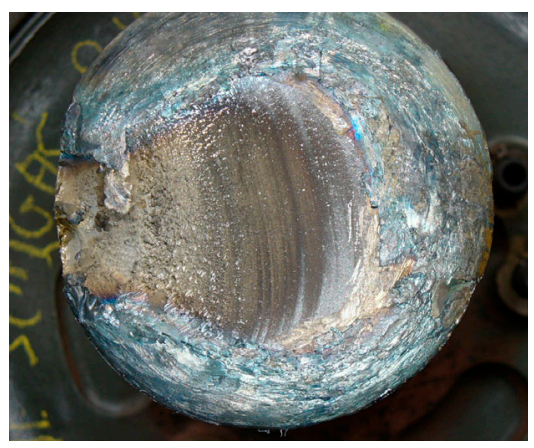

Rys. 2. Złom zmęczeniowy osi od strony części środkowej

Na podstawie otrzymanych wyników można wnioskować, że oś wykonano z niestopowej stali konstrukcyjnej o średniej zawartości węgla i odtlenionej aluminium. Jakość metalurgiczna stali, oceniona poprzez zawartość fosforu i siarki, nie budzi zastrzeżeń. Świadczy o tym bardzo mała zawartość fosforu i siarki (P, S $<0,01 \%)$. Jeśli otrzymane wyniki odnieść do warunków zawartych w normie PN-91/H-84027/3 i karcie UIC 811-1 to należy zauważyć, że materiał osi spełnia wymagania zawarte $\mathrm{w}$ wymienionych dokumentach normatywnych.
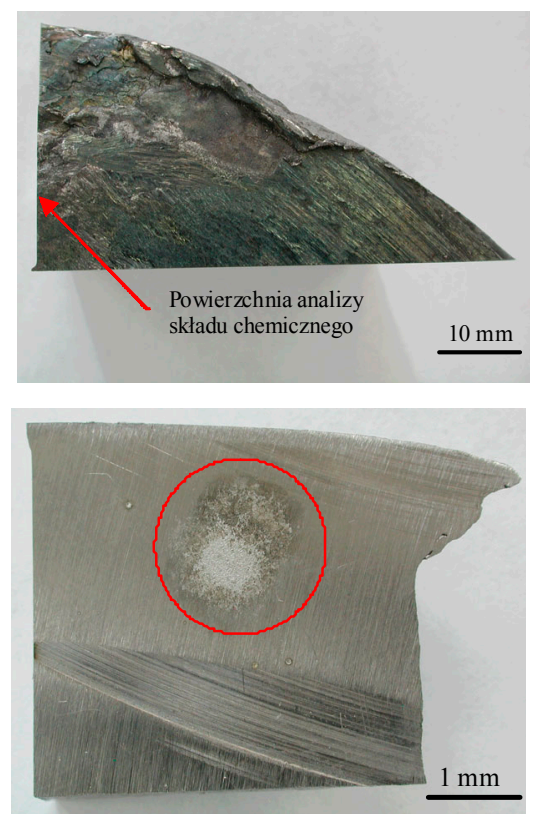

Rys. 3. Makro zdjęcie próbki 1 z oznaczonym miejscem analizy składu chemicznego

Za podstawę określenia własności mechanicznych, zgodnie z normą PN-93/K-91046, przyjęto statyczną próbę rozciagania oraz próbę udarności. Próbki do statycznej próby rozciagania o średnicy $d_{0}=10 \mathrm{~mm}, \mathrm{w}$ ilości 3-ech sztuk, pobrano z części środkowej osi wg schematu zamieszczonego na rys. 4. Dodatkowo wykonano badania na próbkach cylindrycznych o średnicy $d_{0}=5 \mathrm{~mm}$. Próbę udarności przeprowadzono na próbkach poprzecznych i wzdłużnych $\mathrm{z}$ nacięciem $\mathrm{U}$. Próbki poprzeczne i wzdłużne pobrano zgodnie ze schematem zawartym w normie PN-93/K-91046.
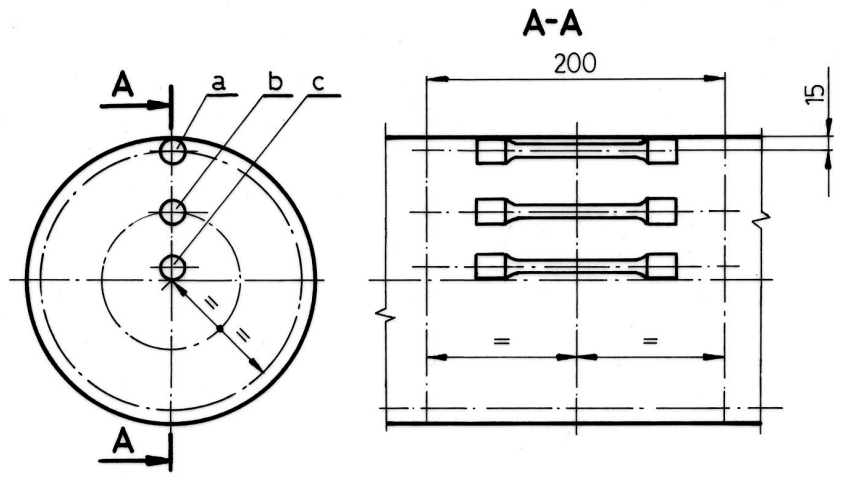

Rys. 4. Lokalizacja próbek do badania wytrzymałości na rozciaganie pobranych z części środkowej osi

Wyniki analizy składu chemicznego stali

\begin{tabular}{|c|c|c|c|c|c|c|c|c|c|c|}
\hline \multirow{2}{*}{ Specyfikacja } & \multicolumn{10}{|c|}{ Zawartość pierwiastków [\% masowe] } \\
\hline & $\mathrm{C}$ & $\mathrm{Si}$ & $\mathrm{Mn}$ & $\mathrm{P}$ & $\mathrm{S}$ & $\mathrm{Cr}$ & $\mathrm{Cu}$ & Mo & $\mathrm{Ni}$ & inne \\
\hline \multirow[b]{2}{*}{ Oś uszkodzona } & 0,28 & 0,23 & 0,94 & 0,00 & 0,00 & 0,09 & 0,24 & 0,00 & 0.12 & \multirow{4}{*}{$\begin{array}{c}\mathrm{Al} .= \\
0,034 \\
\mathrm{~V}= \\
0,001\end{array}$} \\
\hline & 3 & 8 & 4 & 2 & 6 & 7 & 9 & 1 & 3 & \\
\hline Wymagania wg & & & & $\max$ & $\max$ & $\max$ & $\max$ & & $\max$ & \\
\hline PN-91/H- & 0,37 & 0,45 & 1,10 & 0,03 & 0,03 & 0,30 & 0,30 & 1 & 0,30 & \\
\hline Wymagania wg & & & & & 002 & & & & & \\
\hline UIC 811-1 (A1) & 0,40 & 0,50 & 1,20 & $\begin{array}{c}0,02 \\
0\end{array}$ & 0 & 0,30 & 0,30 & 0,08 & 0,30 & - \\
\hline
\end{tabular}


Wyniki badań własności mechanicznych

Tabela 2

\begin{tabular}{|c|c|c|c|c|c|c|c|c|}
\hline \multicolumn{2}{|c|}{ Próbka } & $R_{e}[\mathrm{MPa}]$ & $\begin{array}{c}R_{m} \\
{[\mathrm{MPa}]}\end{array}$ & $\begin{array}{c}A_{5} \\
{[\%]}\end{array}$ & $Z[\%]$ & Próbka & $\begin{array}{c}\text { Praca łamania } \\
{[\mathrm{J}]}\end{array}$ & $\begin{array}{l}\text { Udar- } \\
\text { ność } \\
{\left[\mathrm{J} / \mathrm{cm}^{2}\right]}\end{array}$ \\
\hline \multirow{3}{*}{ 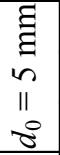 } & $1 p$ & 362 & 619 & 29,5 & 70,3 & $2 \mathrm{P} 1$ & 49 & 98 \\
\hline & $2 p$ & 384 & 623 & 29,0 & 70,2 & $2 \mathrm{P} 2$ & 48 & 96 \\
\hline & $3 p$ & 378 & 620 & 27,1 & 70,7 & $2 \mathrm{P} 3$ & 47 & 94 \\
\hline \multirow{3}{*}{ 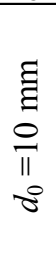 } & $\begin{array}{l}1 \\
\mathrm{P}\end{array}$ & 387 & 610 & 30,4 & 69,3 & $2 \mathrm{~W} 1$ & 63 & 126 \\
\hline & $\begin{array}{l}2 \\
P\end{array}$ & 387 & 609 & 29,1 & 68,7 & $2 \mathrm{~W} 2$ & 67 & 134 \\
\hline & $\begin{array}{l}3 \\
P\end{array}$ & 384 & 608 & 30,4 & 66,4 & $2 \mathrm{~W} 3$ & 62 & 124 \\
\hline
\end{tabular}

Wartości średnie własności mechanicznych stali na podstawie próby rozciągania

Tabela 3

\begin{tabular}{|l|c|c|c|c|}
\hline \multirow{2}{*}{ Wyszczególnienie } & \multicolumn{4}{|c|}{ Własności mechaniczne } \\
\cline { 2 - 5 } & $R_{m}[\mathrm{MPa}]$ & $R_{e}[\mathrm{MPa}]$ & $A_{5}[\%]$ & $Z[\%]$ \\
\hline Próbka $d_{0}=5 \mathrm{~mm}$, czop osi & 620 & 375 & 28,5 & 70,4 \\
\hline Próbka $\mathrm{d}_{0}=10 \mathrm{~mm}$, czop osi & 609 & 386 & 29,9 & 68,1 \\
\hline Wymagania wg PN- & $550 \div 700$ & $\min .350$ & min. 24 & min. 45 \\
\hline Wymagania wg UIC 811-1 dla & $550 \div 650$ & $\geq 320$ & $\geq 22$ & ${ }^{* *}$ \\
\hline *** wskaźnik nie określany na podstawie karty UIC. \\
\hline
\end{tabular}

Wyniki pomiarów udarności

Tabela 4

\begin{tabular}{|l|c|c|c|c|}
\hline \multirow{2}{*}{ Wyszczególnienie } & \multicolumn{2}{|c|}{ Próbki poprzeczne P1, P2, P3 } & \multicolumn{2}{c|}{ Próbki wzdłużn W1, W2, W3 } \\
\cline { 2 - 5 } & $\begin{array}{c}\text { Praca łamania } \\
\mathrm{KU}[\mathrm{J}]\end{array}$ & $\begin{array}{c}\text { Udarność KCU } \\
{\left[\mathrm{J} / \mathrm{cm}^{2}\right]}\end{array}$ & $\begin{array}{c}\text { Praca amania } \\
\mathrm{KU}[\mathrm{J}]\end{array}$ & $\begin{array}{c}\text { Udarność KCU } \\
{\left[\mathrm{J} / \mathrm{cm}^{2}\right]}\end{array}$ \\
\hline Wartość średnia & 48 & 96 & 64 & 128 \\
\hline $\begin{array}{l}\text { Odchylenie standar- } \\
\text { dowe }\end{array}$ & - & 1,63 & - & 4,32 \\
\hline
\end{tabular}

Statyczną próbę rozciagania wykonano na hydraulicznej maszynie wytrzymałościowej typu EU $20 \mathrm{z}$ wykorzystaniem ekstensometrycznych czujników siły (ZEWPN typu CL 14) i przemieszczenia (Epsilon 3542025M-050-LT) podłączonych do komputera poprzez karte pozyskiwania danych DAS 800. Badanie udarności przeprowadzono przy użyciu młota udarnościowego Alpha o energii początkowej 300 $\mathrm{J}$.

Na podstawie przeprowadzonych prób obliczono następujące wielkości:

- $R_{e}$-wyraźną granicę plastyczności [MPa],

$R_{m}$ - wytrzymałość na rozciaganie [MPa],

$A_{5}$ - wydłużenie względne próbki [\%], $Z$ - przewężenie względne próbki w szyjce w momencie pęknięcia [\%], KCU - udarność $\left[\mathrm{J} / \mathrm{cm}^{2}\right]$.
Wyniki badania własności mechanicznych, dla każdej z badanych próbek, zebrano $\mathrm{w}$ tabeli 2, zaś przykładowe wykresy rozciagania przedstawiono na rys. 5 i 6 . Wyniki średnich wartości badanych własności mechanicznych stali zawarto $\mathrm{w}$ tabeli 3 i 4 . Potwierdzają one, że stal P35G posiada dobre własności plastyczne i wytrzymałościowe, a różnice uzyskane dla poszczególnych próbek są nie wielkie, co świadczy o jednorodności materiału.

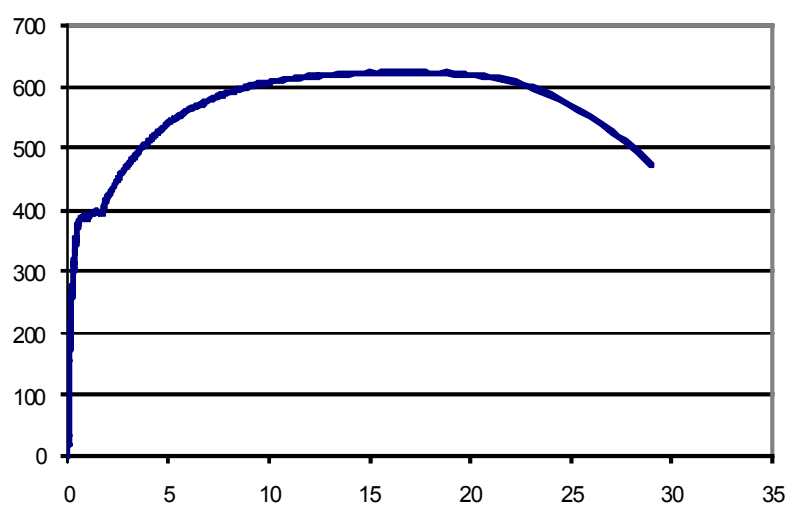

Rys. 5. Przykładowy wykres rozciągania próbki o średnicy $\phi 5 \mathrm{~mm}$

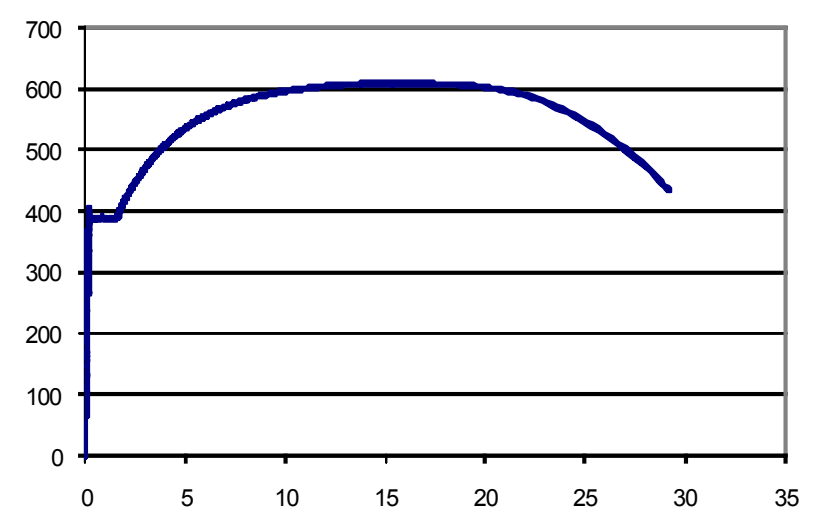

Rys. 6. Przykładowy wykres rozciagania próbki o średnicy $\phi 10 \mathrm{~mm}$

Porównanie średnich wartości wskaźników określających własności wytrzymałościowe $\left(R_{m}, R_{e}\right)$, ciągliwość $\left(A_{5}, Z\right)$ oraz udarność $(\mathrm{KCU}) \mathrm{z}$ danymi zawartymi w normie PN-91/H-84027/03 oraz w karcie UIC 811-1 dla materiału A1 pozwala na stwierdzenie, że materiał osi pod względem własności mechanicznych spełnia wymagania zawarte w cytowanych dokumentach normatywnych. 
Badania makrostruktury zostały przeprowadzone na próbce $\mathrm{w}$ postaci krążka pobranego $\mathrm{z}$ przekroju poprzecznego części środkowej osi, który wytrawiono odczynnikiem Baumanna. Odbitkę próbki wykonano na papierze fotograficznym. Przeprowadzone badania makrostruktury wykazały, że rozkład siarczków jest równomierny na całej powierzchni przekroju poprzecznego osi, bez występowania wyraźnych skupień czy segregacji, co świadczy o poprawnym procesie metalurgicznym stali zastosowanej do produkcji osi nr 341.

Badania mikrostruktury oraz badania fraktograficzne przełomu zmęczeniowego osi wykonano na próbkach zestawionych wraz z ich numeracją zawiera rys. 7. Do badań mikrostruktury i badań fraktograficznych zastosowano dwie próbki oznaczone numerami 2 i 5 (rys. 7). Analizę przełomów w rejonie powierzchni osi wykonano na elektronowym mikroskopie skaningowym JSM 5510LV firmy JEOL. Wyniki tych badań przedstawiono $\mathrm{w}$ postaci topografii przełomów dla próbki 2 na rys. 8. Następnie na próbkach 2 i 5 wykonano zgłady metalograficzne na powierzchniach prostopadłych do powierzchni osi oraz przełomu zmęczeniowego. Po trawieniu 4\% azotalem ujawniono mikrostrukturę wraz $\mathrm{z}$ napoinami $\mathrm{w}$ warstwie wierzchniej, co obrazują rys. 9 i rys. 10 . Na rys. 11 przedstawiono szczegóły mikrostrukturalne warstwy wierzchniej badanej osi w rejonie napoiny (próbka 2) z widocznymi zarodkami pęknięcia kruchego. Na rys. 12 zobrazowano wyniki badań mikrostrukturalnych dla warstwy wierzchniej w próbce $5 \mathrm{w}$ obszarze występowania napoiny. Na kolejnych rysunkach 13 i 14 zaznaczono punkty wykonania pomiarów mikrotwardości metodą Vickersa oraz wyniki tych pomiarów, które zebrano odpowiednio dla próbki $2 \mathrm{w}$ tabeli 5 oraz dla próbki $5 \mathrm{w}$ tabeli 6 . Pomiary mikrotwardości wykonano na twardościomierzu FM 700e firmy Future-Tech Corp. przy obciążeniu $100 \mathrm{~g}(1 \mathrm{~N})$ Dodatkowo, przy pomocy elektronowego mikroskopu skaningowego JSM-5510LV (SEM), wyposażonego w przystawkę do mikroanalizy składu chemicznego EDS firmy IX RF System 500 Digital Processing, dokonano analizy składników mikrostrukturalnych stali konstrukcyjnej zastosowanej do budowy osi. Wyniki tych badań ilustrują rys. 15, 16 i 17oraz dane zawarte $\mathrm{w}$ tabelach 7-9.

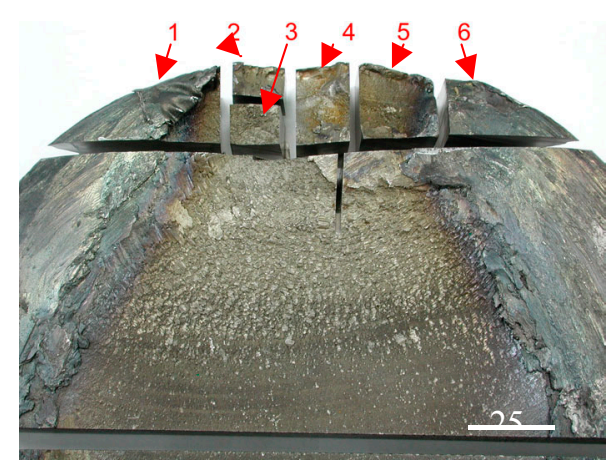

Rys. 7. Przełom osi w rejonie zarodkowania pęknięcia zmęczeniowego po wprowadzeniu oznaczeń próbek metalograficznych
Badania mikrostruktury stali, przeprowadzone na zgładach trawionych $4 \%$ azotalem przy zastosowaniu mikroskopu skaningowego wykazały, że zastosowany do produkcji osi nr 341 gatunek stali $\mathrm{P} 35 \mathrm{G}$ posiada drobnoziarnistą strukturę ferrytyczno-perlityczną, odpowiadająca wzorcowi nr 8-9 wg skali wzorców zawartych w PN-84/H-04507/01,co obrazuje rys. 12e, z niewielką zawartością wydłużonych siarczków manganu (rys. 15 i 16) lub krzemianów (rys. 17).

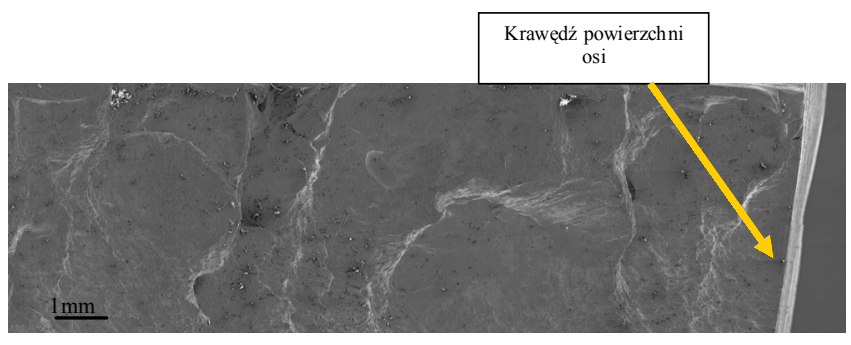

Rys. 8. Topografia przełomu w próbce $2 \mathrm{w}$ strefie zarodkowania pęknięcia zmęczeniowego

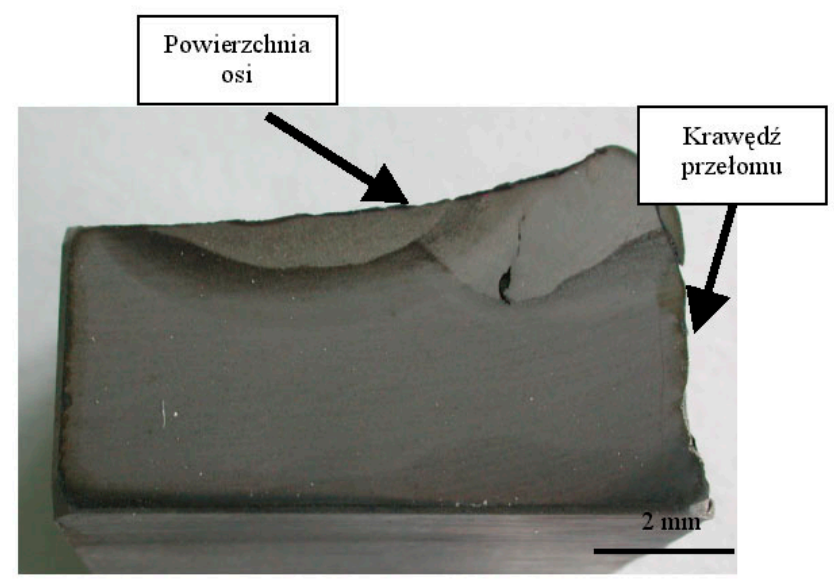

Rys. 9. Pęknięcie w napoinie wykonanej na powierzchni osi - próbka 2

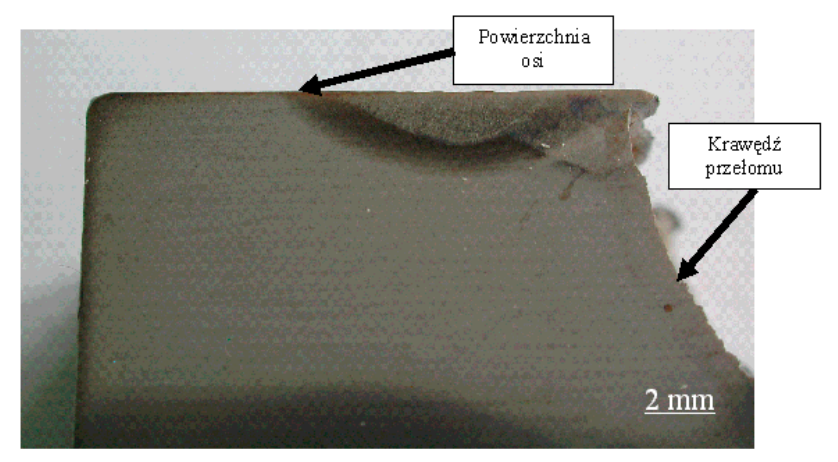

Rys. 10. Napoina wykonaną w warstwie wierzchniej osi - próbka 5 
a)

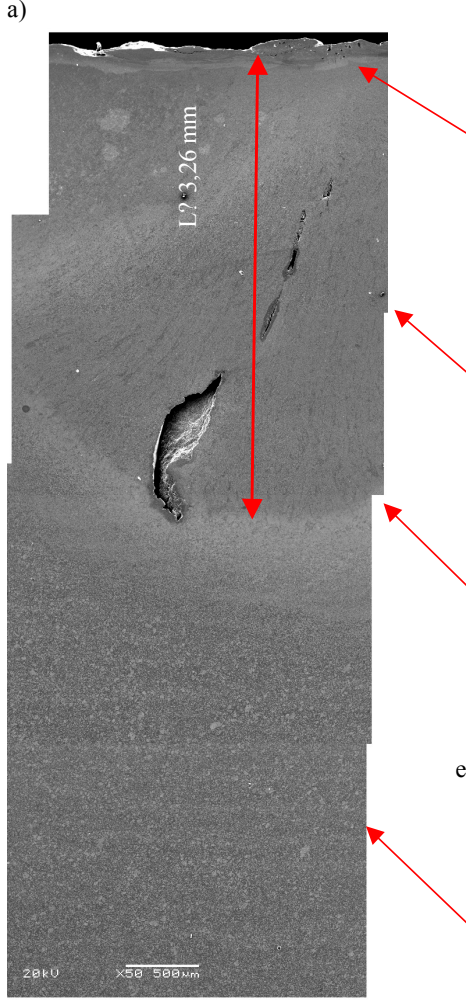

b)

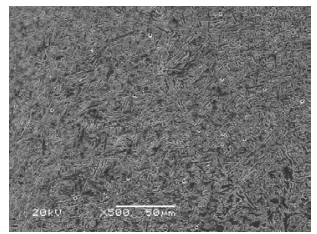

c)

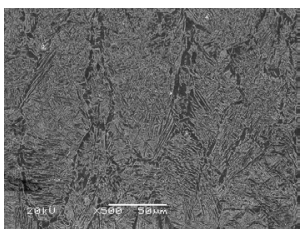

d)
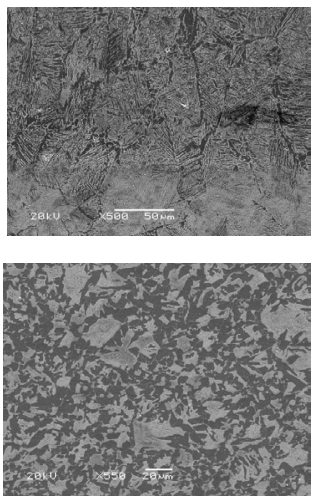

Rys. 11. Mikrostruktura osi warstwie wierzchniej w próbki 2: a) pęknięcie napoiny, b) mikrostruktura warstwy wierzchniej, c) strefa dendrytycznej budowy napoiny, d) mikrostruktura w strefie przejściowej, e) materiał rodzimy

a)

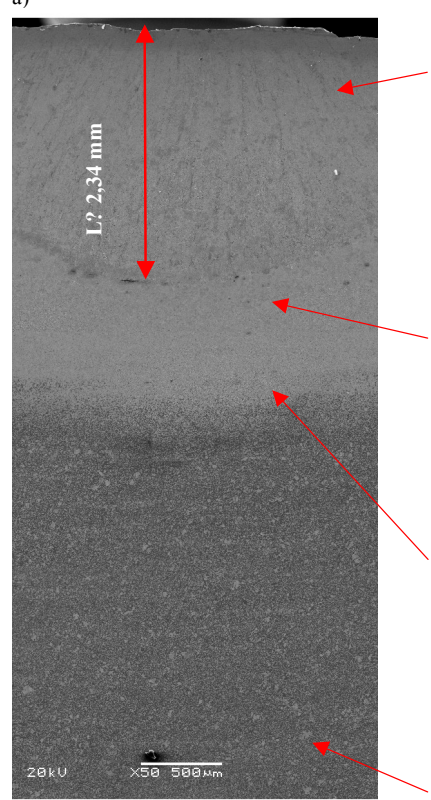

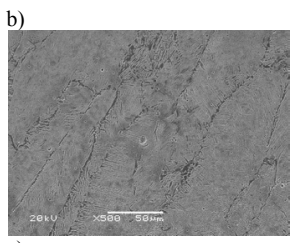
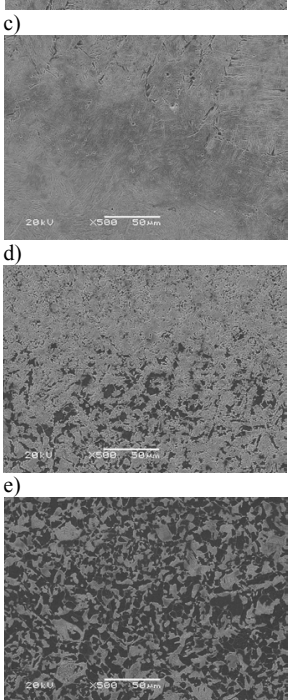

Rys. 12. Mikrostruktura napoiny w próbce 5; a) ogólny widok napoiny, b) budowa dendrytyczna, c) mikrostruktura w strefie przejściowej d), strefa wpływu ciepła, e) materiał rodzimy

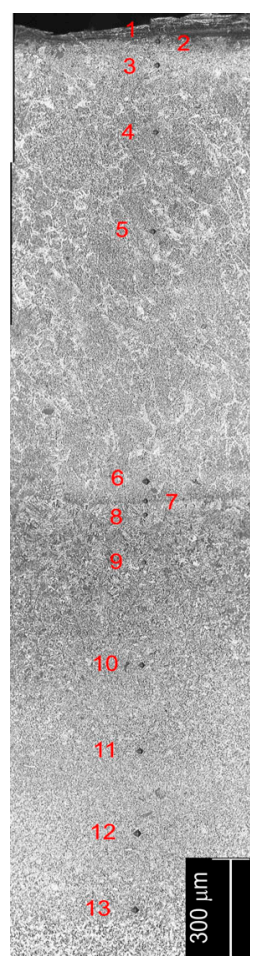

Pomiary mikrotwardości Tabela 5 napoiny $w$ próbce 2

\begin{tabular}{|c|c|c|c|}
\hline \multirow{2}{*}{$\begin{array}{c}\text { Nr odci- } \\
\text { ski }\end{array}$} & \multicolumn{2}{|c|}{ Mikrotwardość 100} & \multirow{2}{*}{ Uwagi } \\
\cline { 2 - 3 } & HV & HRC & \\
\hline 1 & 608 & 56 & $\begin{array}{c}\text { Warstwa wierzch- } \\
\text { nia }\end{array}$ \\
\hline 2 & 392 & 40 & Spoina dendryty \\
\hline 3 & 409 & 42 & Spoina dendryty \\
\hline 4 & 360 & 37 & Spoina dendryty \\
\hline 5 & 380 & 39 & Spoina dendryty \\
\hline 6 & 311 & 31 & Spoina dendryty \\
\hline 7 & 485 & 48 & SWC \\
\hline 8 & 551 & 52 & SWC \\
\hline 9 & 545 & 52 & SWC \\
\hline 10 & 344 & 35 & SWC \\
\hline 11 & 288 & 28 & SWC \\
\hline 12 & 272 & 26 & SWC \\
\hline 13 & 228 & 18 & MR \\
\hline
\end{tabular}

SWC - strefa wpływu ciepła, MR - materiał rodzimy

Rys. 13. Mikrostruktura napoiny w próbce 2 z oznaczonymi miejscami pomiaru mikrotwardości

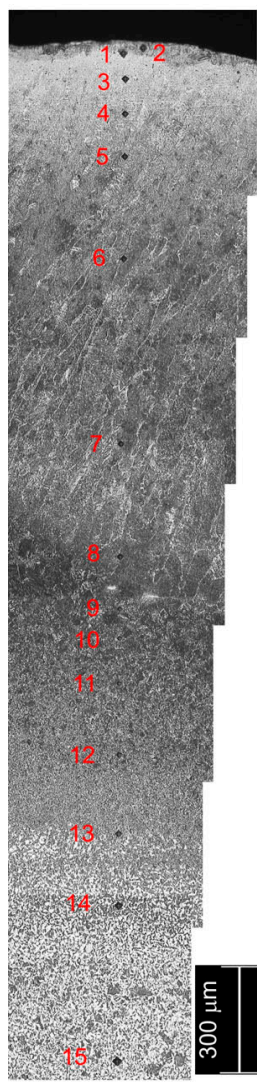

Pomiary mikrotwardości Tabela 6 napoiny w próbce 5

\begin{tabular}{|c|c|c|c|}
\hline \multirow{2}{*}{$\begin{array}{c}\text { Nr } \\
\text { odciski }\end{array}$} & \multicolumn{2}{|c|}{ Mikrotwardość 100 } & \multirow{2}{*}{ Uwagi } \\
\cline { 2 - 3 } & HV & HRC & \\
\hline 1 & 332 & 34 & Warstwa wierzchnia \\
\hline 2 & 398 & 41 & Warstwa wierzchnia \\
\hline 3 & 362 & 37 & napoina \\
\hline 4 & 383 & 39 & napoina \\
\hline 5 & 382 & 39 & napoina dendryty \\
\hline 6 & 367 & 37 & napoina dendryty \\
\hline 7 & 350 & 36 & napoina dendryty \\
\hline 8 & 365 & 37 & Przed SWC \\
\hline 9 & 425 & 43 & SWC \\
\hline 10 & 462 & 46 & SWC \\
\hline 11 & 402 & 41 & SWC \\
\hline 12 & 361 & 37 & SWC \\
\hline 13 & 338 & 34 & SWC \\
\hline 14 & 307 & 31 & SWC \\
\hline 15 & 232 & 19 & MR \\
\hline
\end{tabular}

Rys. 14. Mikrostruktura napoiny w próbce 5 z oznaczonymi miejscami pomiaru mikrotwardości 
a)

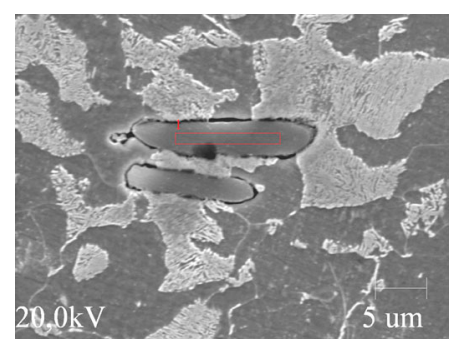

T a b e l a 7

Sklad chemiczny analizowanego wtrącenia

\begin{tabular}{|c|c|r|c|c|}
\hline Pierwiastek & Orbita & $\begin{array}{c}\text { Intensywnośćc } \\
(\mathrm{c} / \mathrm{s})\end{array}$ & $\begin{array}{c}\text { Błąd } \\
\text { 2-sig }\end{array}$ & $\begin{array}{c}\text { zawartość } \\
\text { \% wag. }\end{array}$ \\
\hline $\mathrm{O}$ & $\mathrm{K} \alpha$ & 7,60 & 1,007 & 4,34 \\
\hline $\mathrm{Al}$ & $\mathrm{K} \alpha$ & 3,31 & 0,664 & 0,24 \\
\hline $\mathrm{Si}$ & $\mathrm{K} \alpha$ & 0,69 & 0,303 & 0,04 \\
\hline $\mathrm{S}$ & $\mathrm{K} \alpha$ & 790,29 & 10,26 & 41,68 \\
\hline $\mathrm{Mn}$ & $\mathrm{K} \alpha$ & 471,97 & 7,933 & 41,66 \\
\hline $\mathrm{Fe}$ & $\mathrm{K} \alpha$ & 120,98 & 4,016 & 12,06 \\
\hline
\end{tabular}

a)

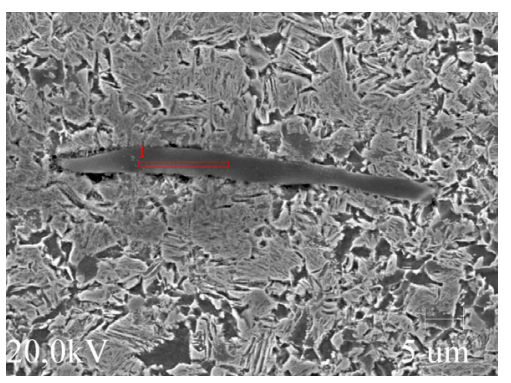

Tabela 8

Skład chemiczny analizowanego wtrącenia

\begin{tabular}{|c|c|c|c|c|}
\hline $\begin{array}{c}\text { Pierwia- } \\
\text { stek }\end{array}$ & $\begin{array}{c}\text { Orbi- } \\
\text { ta }\end{array}$ & $\begin{array}{c}\text { Intensyw- } \\
\text { ność } \\
(\mathrm{c} / \mathrm{s})\end{array}$ & $\begin{array}{c}\text { Błąd } \\
\text { 2-sig }\end{array}$ & $\begin{array}{c}\text { zawar- } \\
\text { tość } \\
\% \text { wag. }\end{array}$ \\
\hline $\mathrm{S}$ & $\mathrm{K} \alpha$ & 783,36 & $\begin{array}{c}10,21 \\
9\end{array}$ & 46,84 \\
\hline $\mathrm{Mn}$ & $\mathrm{K} \alpha$ & 508,84 & 8,236 & 53,16 \\
\hline
\end{tabular}

b)

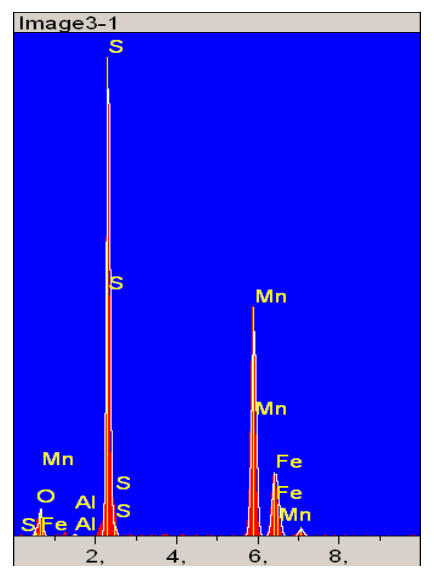

Rys. 15. Analiza składu chemicznego wtrącenia niemetalicznego w próbce 2: a) obszar analizy, b) widmo charakterystycznego promieniowania rentgenowskiego

b)

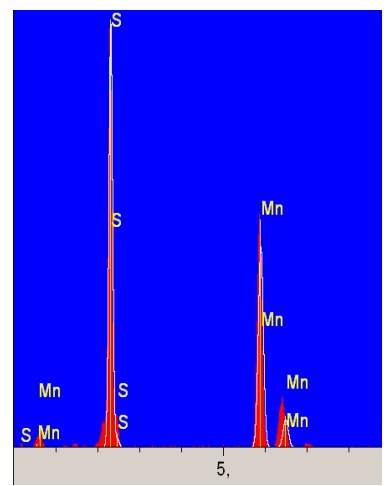

Rys. 16. Analiza składu chemicznego wtrącenia niemetalicznego typu MnS w próbce5: a) obszar analizy, b) widmo charakterystycznego promieniowania rentgenowskiego a)

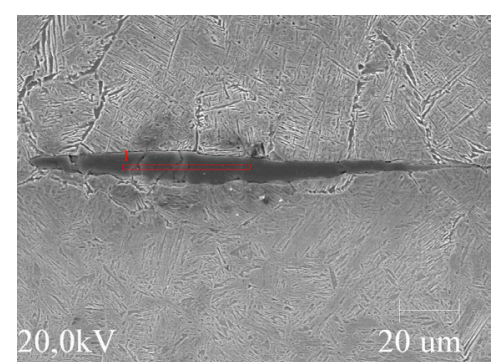

T a b e l a 9

Sklad chemiczny analizowanego wtrącenia

\begin{tabular}{|c|c|c|c|c|}
\hline $\begin{array}{c}\text { Pier- } \\
\text { wiastek }\end{array}$ & Orbita & $\begin{array}{c}\text { Inten- } \\
\text { sywność } \\
(\mathrm{c} / \mathrm{s})\end{array}$ & $\begin{array}{c}\text { Błąd } \\
2 \text {-sig }\end{array}$ & $\begin{array}{c}\text { zawar- } \\
\text { tość } \\
\text { \% wag. }\end{array}$ \\
\hline $\mathrm{O}$ & $\mathrm{K} \alpha$ & 97,03 & 3,597 & 36,465 \\
\hline $\mathrm{Al}$ & $\mathrm{K} \alpha$ & 126,33 & 4,104 & 9,617 \\
\hline $\mathrm{Si}$ & $\mathrm{K} \alpha$ & 316,70 & 6,498 & 21,848 \\
\hline $\mathrm{Mn}$ & $\mathrm{K} \alpha$ & 283,52 & 6,148 & 27,997 \\
\hline $\mathrm{Fe}$ & $\mathrm{K} \alpha$ & 36,71 & 2,212 & 4,073 \\
\hline
\end{tabular}

b)

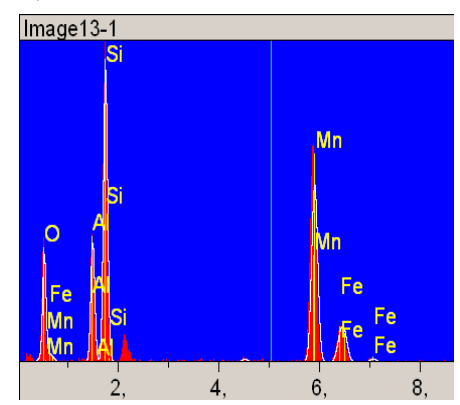

Rys. 17. Analiza składu chemicznego złożonego wtrącenia niemetalicznego w próbce 5 zaznaczonego okręgiem na rys. 13: a) obszar analizy, b) widmo charakterystycznego promieniowania rentgenowskiego 
Szczegółowe badania fraktograficzne przeprowadzone na próbkach 2 i 5, których wyniki przedstawiono na serii mikrofotografii, rys. $8-14$ oraz w tabelach 5 i 6, pokazują, że bezpośrednią przyczyną katastrofalnego pęknięcia osi była napoina o głębokości od $2 \mathrm{~mm}$ do około $3 \mathrm{~mm}$ wykonana na powierzchni osi. Wyraźnie potwierdzają to wyniki pomiarów mikrotwardości w rejonie napoiny, gdzie twardość stali jest co najmniej dwukrotnie wyższa od twardości materiału rodzimego $\left(\mathrm{HV}_{\text {stali }}\right.$ ? 230), zaś napoiny $\mathrm{w}$ próbce 2 (HV608-H300), a w próbce 5 (HV409-HV285).

Bardzo duże różnice w twardości napoiny i materiału osi, najprawdopodobniej spowodowane znaczną szybkością chłodzenia podczas procesu napawania, musiały wywołać znaczne naprężenia cieplne i strukturalne. W wyniku takiego przebiegu zjawiska powstały zarodki kruchych pęknięć, jak to zaobserwowano w próbce 2 (rys. 9 i rys. 11) o głębokości około $3 \mathrm{~mm}$. Jak wynika $z$ analizy fraktograficznej wykonanej przy zastosowaniu SEM, te kilkumilimetrowe pęknięcia były bezpośrednią przyczyną stopniowego rozprzestrzenienia się pęknięcia zmęczeniowego. Szczegółowe badania powierzchni pękania były niemożliwe ze względu na znaczne mechaniczne zniszczenie powierzchni przełomu.

\section{Podsumowanie}

Przeprowadzone badania laboratoryjne, obejmujące badania składu chemicznego, własności mechanicznych oraz makro i mikrostruktury potwierdziły, że zastosowana na oś 341 stal P35G spełnia wymagania zawarte w normie PN-93/K-91046.

Ocena makroskopowa przełomu pozwala wnioskować, że jest on następstwem karbu technologicznego w strefie szczególnie wytężonej, to jest promienia przejściowego pomiędzy czopem spoczynkowym (podpiaściem) a częścią środkową osi.

Badania fraktograficzne przełomu zmęczeniowego osi nr 341 wykazały, że bezpośrednią przyczyną pęknięcia osi było wykonanie napoiny, o głębokości od 2-3 mm, w strefie przejściowej pomiędzy czopem spoczynkowym osi a częścią środkową.

Szczegółowe badania powierzchni pękania, w celu wyjaśnienia mechanizmu propagacji pęknięcia, były niemożliwe $\mathrm{z}$ uwagi na mechaniczne naruszenie struktury powierzchni przełomu $\mathrm{w}$ procesie eksploatacji.

\section{Lit e rat u ra}

[1] Badania materiałowe i wytrzymałościowe uszkodzonej osi $\mathrm{nr} 341$ lokomotywy EP09-021 zgodnie z norma PN93/K-91046, Politechnika Krakowska, Kraków, maj 2009.

[2] Ko cańda S., Zmęczeniowe niszczenie metali, WNT, Warszawa 1978.

[3] Tutecki A., Sorochtej M., Studium analityczne montażu koła z osia w zestawach kołowych, Zeszyty Naukowe Politechniki Ślaskiej, Seria: Transport, z. 7, Gliwice 1987.

[4] Ta n a ka S., Hiros e F.: Fatique behavior of fretting cracks at the wheel seat of car axles, The Sixth International Wheelset Congress, Colorado Springs, October 1978.

[5] Karwala K., Kulikowski H., Tutecki A., Technologiczne problemy trwałości zestawów kołowych pod katem przystosowania pojazdów szynowych do zwiększonych prędkości jazdy, Rozprawa doktorska, Politechnika Krakowska, Kraków 1991.

[6] Broś J., Partyla M., Tulecki A., The kinds of wear and failures of bearing surface of interference joints wheel sats of rail vehicles, 3-rd Conference on Tribology, Budapest 1983.

[7] Bak R., Grajek K., Zacharski M., Metoda numeryczna analizy statycznej stanu naprężenia $w$ kolejowych zestawach kolowych, Zeszyty Naukowe IPKM Pol. Ślaska, z. 27/61, Gliwice 1977.

[8] Broś J., Tulecki A., Badania modelowe wytrzymatości zmęczeniowej elementów połaczeń wciskowych $w$ zestawach kołowych, Zeszyty Naukowe Politechniki Ślqskiej, Seria: Transport, z. 14, Gliwice 1989. 